\title{
Kidney Stone Treatment in the Anomalous Kidney with Retrograde Intrarenal Surgery: A Matched Pair Analysis
}

\author{
Anomalik Böbrek Taş Tedavisinde Retrograd Intrarenal Cerrahi: Çift Eşleştirilmiş Analiz
}

\author{
(1) Sercan Sarı1, (1) Mehmet Çağlar Çakıcı², (1) Aykut Aykaç3, (1) Özer Baran³, (1) Ibrahim Güven Kartal4, (1) Hakkı Uğur Özok³, \\ (D) Ahmet Nihat Karakoyunlu4, (D) Azmi Levent Sağnak4 \\ 1 Yozgat Bozok University Faculty of Medicine, Department of Urology, Yozgat, Turkiye \\ 2 Medeniyet University Göztepe Training and Research Hospital, Clinic of Urology, Istanbul, Turkiye \\ ${ }^{3}$ Karabuk University Faculty of Medicine, Department of Urology Karabük, Turkiye \\ ${ }^{4}$ University of Health Science Turkiye, Ankara Dışkapı Yıldırım Beyazıt Training and Research Hospital, Clinic of Urology, Ankara, Turkiye
}

\section{What's known on the subject? and What does the study add?}

Retrograde intrarenal surgery (RIRS) is a recently popular treatment method for kidney stones. But in anomalous kidney stones, RIRS may be challenging due to impaired urine drainage and changed anatomic structure. There are studies about RIRS in anomalous kidney stone treatment. But our study shows collectively the experience of RIRS in different types of anomalies.

\begin{abstract}
Objective: To show our retrograde intrarenal surgery (RIRS) experience in anomalous kidney stones and compare its safety and efficiency with normal kidney stones.

Materials and Methods: Between 2012 and 2018, patient data was reviewed retrospectively and 1700 procedures were taken into consideration. Forty-seven anomalous kidney stones were included in the study (group A). In these patients, 18 had calyx diverticulum, 12 had horseshoe kidney, 8 had ureteral duplication, 2 had ectopic kidneys, 1 had malrotation, and 1 had bifid pelvis. After making a matched pair analysis, 47 normal kidney stones with similar demographic and stone characteristics were included in our study (group N). Demographic, stone, intraoperative and postoperative data were recorded. We compared these groups regarding efficiency and safety.

Results: Average scope time, hospitalization time, and postoperative double J-stent rate were higher in group A. The difference was statistically insignificant $(p>0.05)$. Ureteral access sheath usage was higher in group $N$, though the difference was statistically insignificant ( $p=0.63)$. Stonefree rates and success rates were higher in group $N$ though the difference was not statistically significant ( $p>0.05$ ). The rate of complications was statistically significantly higher in group $A(p=0.02)$.

Conclusion: RIRS can be used in the management of anomalous kidney stones. It is an efficient and safe method. Prospective and larger patient numbered studies are needed.
\end{abstract}

Keywords: Anomalous, Matched pair, RIRC

Öz

Amaç: Anomalik böbrek taşlarında retrograd intrarenal cerrahi (RiRC) deneyimimizi göstermek ve normal böbrek taşları ile güvenlik ve etkinliğini karşılaştırmaktır.

Gereç ve Yöntem: 2012-2018 yılları arasında veriler retrospektif olarak tarandı. Bin yedi yüz işlem değerlendirildi. Kırk yedi anomalik böbrek taşı çalışmaya alındı (grup A). Bunlardan 18'inde kaliks divertikülü, 12'sinde atnalı böbrek, 8'inde üreteral duplikasyon, 2'sinde ektopik böbrek, birinde malrotasyon ve birinde bifid pelvis mevcuttu. Çift eşleştirilmiş analiz sonrası benzer özelliklere sahip 47 normal böbrek taşı çalışmaya alındı (grup N). Demografik, taş, intraoperatif ve postoperatif veriler kaydedildi. Gruplar etkinlik ve güvenilirlik açısından karşılaştırıldı.

Bulgular: Ortalama skopi süresi, hastanede kalış süresi ve postoperatif Double-J stent oranı A grubunda yüksekti. Aradaki fark istatiksel olarak anlamsızdı ( $p>0,05)$. Üreteral akses kılıf kullanımı N grubunda yüksekti. Aradaki fark istatiksel olarak anlamsızdı ( $p=0,63)$. Taşsızlık ve başarı oranı N

Correspondence: Sercan Sarı MD, Yozgat Bozok University Faculty of Medicine, Department of Urology, Yozgat, Turkiye

Phone: +90 3542127060 E-mail: sercansari92@hotmail.com ORCID-ID: orcid.org/0000-0002-0994-3799

Received: 29.11.2019 Accepted: 11.02.2020

Cite this article as: Sarı Y, Çakıcı MÇ, Aykaç A, Baran Ö, Kartal IG, Özok HU, Karakoyunlu AN, Sağnak AL. Kidney Stone Treatment in the Anomalous Kidney with Retrograde Intrarenal Surgery; A Matched Pair Analysis. J Urol Surg 2020;7(3):166-171.

๑Copyright 2020 by the Association of Urological Surgery / Journal of Urological Surgery published by Galenos Publishing House. 
grubunda yüksekti. Aradaki fark istatistiksel olarak anlamlı değildi. Komplikasyon oranı A grubunda istatiksel olarak anlamlı şekilde yüksekti ( $p=0,02$ ). Sonuç: RiRC anomalik böbrek taş tedavisinde kullanılabilecek etkin ve güvenilir bir yöntemdir. Prospetif ve yüksek sayılı çalışmalara ihtiyaç vardır. Anahtar Kelimeler: Anomalik, Çift eşleştirilmiş, RIRC

\section{Introduction}

Kidney anomalies are seen in 300-1000 births $(1,2)$. Impaired urine drainage increases stone formation in anomalous kidneys $(2,3)$. Stone management is important in anomalous kidneys. Shock wave lithotripsy (SWL) is a method used in management. SWL is a non-invasive method with stone clearance rate of $67.8 \%$ (54\%-82\%) (4), but impaired urine drainage and changed anatomic structure may worsen stone clearance (5). Another method for management is percutaneous nephrolithotomy (PNL). PNL is the first choice for treatment of stones $>2 \mathrm{~cm}$ in size, but serious complications can be encountered by using this process. It has a success rate of approximately $87.5 \%$. The position of the patient and complications (pneumothorax, hemorrhage, nephro-pleural fistula) are disadvantages of PNL (6). The other management options are laparoscopic pyelolithotomy and laparoscopy-assisted PNL. These methods are more invasive than endoscopic methods (7). Retrograde intrarenal surgery (RIRS) was firstly used in the late $20^{\text {th }}$ century, and its usage increased with advanced technology $(8,9)$. The development of flexible ureteroscope size and deflection technologies expanded RIRS usage areas (10-14). Serious complications are rarely seen in RIRS method $(15,16)$. RIRS can be used for the treatment of anomalous kidney stones. In our study, we aimed to show our RIRS experience in anomalous kidney stones and compare its safety and efficiency with normal kidney stones.

\section{Materials and Methods}

Between 2012 and 2018, data collected was reviewed retrospectively and 1700 procedures were taken into consideration. For anomalous kidney stones, 47 procedures were included in the study. In these patients, 18 had calyx diverticulum (CD), 12 had horseshoe kidney (HSK), 8 had ureteral duplication, 2 had ectopic kidney (EK), 1 had malrotation (M), and 1 had bifid pelvis. For non-anomalous kidney stones, 47 procedures were selected and enrolled. The anomalous procedures were divided into groups according to stone size 5-10 mm, 11-15 mm, 16-20 $\mathrm{mm}, 21-25 \mathrm{~mm}, 26-30 \mathrm{~mm}, 31-35 \mathrm{~mm}, 36-40 \mathrm{~mm}, 41-45 \mathrm{~mm}$, 46-50 $\mathrm{mm}$, and 51-55 $\mathrm{mm}$. The similar number of procedures were selected from the non-anomalous procedures randomly. The randomization was made similarly for the criteria such as stone laterality, stone number and stone localization. Patients were informed about treatment methods. Treatment method was chosen according to patient and surgeon choice.
Common blood count, serum biochemical values, bleeding and coagulation profile, urine analysis and urine culture were obtained for all patients preoperatively. All urine cultures were provided preoperativesterile. Different radiological methods were used kidney-ureter-bladder graphy (KUBG), ultrasonography (US), intravenous urography, and/or computerized tomography. For non-opaque stones, the stone diameter was measured with the US. For opaque stones, KUBG was used. In multiple stones, the sum of the longest diameters of each stone was defined as stone diameter. Informed consent was taken from all patients before the operation. All procedures performed in studies involving human participants were in accordance with the ethical standards of the institutional and/or national research committee and with the 1964 Helsinki Declaration and its later amendments or comparable ethical standards.

\section{Surgical Procedure}

Parenteral antibiotic was applied one hour before operation. RIRS operation was applied under general anesthesia in the lithotomy position. Semi rigid renoscopy was applied, and the hydrophilic guide wire was inserted into the ureter under fluoroscopic control. Ureteral access sheath (UAS) (9.5 French (Fr)/11.5 Fr or $11 / 13 \mathrm{Fr}$ (Elite Flex, Ankara, Turkiye) was placed over the guidewire under fluoroscopic control. Unless UAS placed, flexible ureterorenoscope (Flex- $\mathrm{X}^{2}$; Karl Storz, Tutlingen, Germany) was placed over the guidewire. And renal access was supplied. Lithotripsy was made with 200-micron holmium laser probe (Holmium:Yttrium Aluminum Garnet (Ho-YAG) Laser:Dornier Meditech; Munich,Germany). Lithotripsy was performed with 8-10 Hertz frequency and 1.2-1.5 joule power. Dusting and fragmentation methods were used according to surgeon's choice. Double-J (DJ) stent was placed due to intraoperative conditions (bleeding, residual fragments, etc). DJ stent was taken under sedation three weeks later. All calyxes were controlled with flexible ureteroscope under fluoroscopic control at the end of the operation. To evaluate success, KUBG was used for opaque stones; the US was used for non-opaque stones on the postoperative first day. The patients were followed for six months. Being stone free or having $<3 \mathrm{~mm}$ residual fragment on intraoperative and postoperative controls (first day and month) were described as successful. In case of being unsuccessful second procedure was planned three weeks later. Complications were evaluated according to Clavien-Dindo classification. 


\section{Statistical Analysis}

Data was analyzed using the Statistical Package for Social Sciences (SPSS 16.0, Chicago). One Sample Kolmogorov-Smirnov test was applied to numeric variables. Numeric variables that are normally distributed were reported in mean \pm standard deviation. The distribution was not normal for the variables except age, body mass index (BMI) due to the p-values $<0.05$. Student's t-test was used to compare numeric variables while discrete variables were analyzed using Pearson's chi-square test. Mann-Whitney $\mathrm{U}$ test was used to compare categorical variables while $p$-values $<0.05$ were considered statistically significant. Quantitative variables analyzed include age and BMI. Qualitative variables analyzed include sex, stone laterality, stone localization, access sheath usage, DJ stent usage, complication rate, previous surgery history, preoperative DJ stent usage, anticoagulant usage, success, and residual fragment rates.

\section{Results}

Ninety-four procedures were included in our study, and were divided into two groups: Anomalous group (group A) and non-anomalous group (group N). For demographic and stone characteristics, there was no statistically significant difference for age, BMI and gender between two groups. Previous surgery history, anticoagulant usage, stone laterality and stone localization were similar between two groups (Table 1). Stone burden was statistically insignificantly higher in Group $\mathrm{N}$. Preoperative DJ stent usage and stone number was higher in group $\mathrm{N}$ but the difference was not statistically significant ( $>$ >0.05) (Table 1).

For intraoperative and postoperative data, average operation time, average scope time, hospitalization time and postoperative DJ stent rate were higher in group A. The difference was insignificant $(p>0.05)$. UAS usage was insignificantly higher in group N. Stone-free rate and success rate were higher in group N, though the difference was not statistically significant $(p=0.18)$. For complications, the complication rate was statistically significantly higher in group A ( $p=0.02)$ (Table 2$)$. Most of the complications were minor complications.

\section{Discussion}

Stone formation risk increases in anomalous kidneys and stone management is an important issue $(2,3)$. RIRS can be used in the management of anomalous kidney stones due to its new technology and rare serious complication rate (10-17). In our study, we aimed to report our RIRS experience in patients who have anomalous kidney stones and compare this experience with normal kidney stones. Ninety-four procedures were included in our study.
In our study, the largest patient group was in CD group. CD is an abnormal cavity that has no draining papilla that is related with renal collecting system through the narrow diverticula neck (18). PNL is the most used method for stone management in CD patients. In this method, diverticula can be reached through percutaneous access. Diverticular urothelium can be fulgurated. If draining infundibulum is found, it can be fulgurated and incised or dilated with nephrostomy tube. 75-100\% success rate is reported (19-21). In RIRS procedure, stone fragmentation and diverticula neck incision can be made with laser. Combining with SWL, success rate is about $90 \%$. If accessible diverticula neck is present, RIRS can be used for especially $<2 \mathrm{~cm}$ sized upper and mid pole stones treatment (18). In our study, the success rate was $72 \%$. The average stone size was $17.94 \mathrm{~mm}$.

HSK is the most frequent congenital genitourinary anomaly. It is observed in 1 in every 400 births. The kidney stone is present in $20 \%$ of HSK patients $(2,3)$. One of the methods used for kidney stone management in HSK patients is SWL. Limited urine drainage and excessive stone-skin distance decrease success of SWL (22). PNL is the most used method, but serious complications can be seen (5). RIRS is an another treatment method. In 2005, Weizer et al. (1) reported 75\% stone-free rate in HSK patients who have $<2 \mathrm{~cm}$ sized kidney stones. No complication reported (1). In 2010, Molimard et al. (23) reported 53\% stone-free rate in 17 HSK patients. The average stone size was $16 \mathrm{~mm}$. In another

Table 1. Demographic and stone characteristics

\begin{tabular}{|c|c|c|c|}
\hline & $\begin{array}{l}\text { Group N } \\
(n=47)\end{array}$ & $\begin{array}{l}\text { Group A } \\
(n=47)\end{array}$ & p \\
\hline Age (years) ( \pm SD) & $42.72 \pm 15.52$ & $47.72 \pm 17.90$ & 0.317 \\
\hline Gender (M/F) & $31 / 16$ & $32 / 15$ & 0.826 \\
\hline BMI $\left(\mathrm{kg} / \mathrm{m}^{2}\right)( \pm \mathrm{SD})$ & $24.78 \pm 4.21$ & $25.63 \pm 4.47$ & 0.724 \\
\hline $\begin{array}{l}\text { Previous surgery history } \\
(n, \%)\end{array}$ & $22(46.8)$ & $23(48.9)$ & 0.836 \\
\hline $\begin{array}{l}\text { Anticoagulant usage } \\
(n, \%)\end{array}$ & 0 & $1(2.1)$ & 0.315 \\
\hline $\begin{array}{l}\text { Preoperative DJ stent } \\
\text { usage }(n, \%)\end{array}$ & $3(6.4)$ & $6(12.8)$ & 0.293 \\
\hline Stone laterality (R/L) (n) & $21 / 26$ & $20 / 26$ & 0.599 \\
\hline Stone number $(n)( \pm S D)$ & $1.51 \pm 0.90$ & $1.53 \pm 0.85$ & 0.883 \\
\hline Stone burden $(\mathrm{mm})( \pm \mathrm{SD})$ & $17.38 \pm 10.48$ & $16.87 \pm 10.64$ & 0.802 \\
\hline Stone localization $(\mathrm{n}, \%)$ & & & 0.999 \\
\hline Upper calyx $(n, \%)$ & $8(17)$ & $9(19.1)$ & - \\
\hline Lower calyx (n, \%) & $12(25.5)$ & $12(25.5)$ & - \\
\hline Mid calyx $(n, 0)$ & $8(17)$ & $8(17)$ & - \\
\hline Pelvis $(n, \%)$ & $9(19.1)$ & $9(19.1)$ & - \\
\hline Multicaliceal $(n, \%)$ & $5(10.6)$ & $5(10.6)$ & - \\
\hline Proximal ureter $(\mathrm{n}, \%)$ & $5(10.6)$ & $4(8.5)$ & - \\
\hline
\end{tabular}




\begin{tabular}{|c|c|c|c|}
\hline & $\begin{array}{l}\text { Group N } \\
(n=47)\end{array}$ & $\begin{array}{l}\text { Group A } \\
(n=47)\end{array}$ & $\mathbf{p}$ \\
\hline $\begin{array}{l}\text { Average operation } \\
\text { Time }(\min \pm \text { SD) }\end{array}$ & $44.65 \pm 15.42$ & $52.12 \pm 23.65$ & 0.086 \\
\hline $\begin{array}{l}\text { Average scopy time } \\
\text { (Sc } \pm \text { SD) }\end{array}$ & $36.10 \pm 28.34$ & $46.85 \pm 44.84$ & 0.282 \\
\hline Postoperative DJ stent, n (\%) & $33(70.2)$ & $34(72.3)$ & 0.820 \\
\hline $\begin{array}{l}\text { Uretheral access sheath } \\
\text { usage, } \mathrm{n}(\%)\end{array}$ & $36(76.6)$ & $34(72.3)$ & 0.636 \\
\hline $\begin{array}{l}\text { Average hospitalization time } \\
( \pm \text { SD) (day) }\end{array}$ & $1.08 \pm 0.41$ & $1.27 \pm 1.22$ & 0.401 \\
\hline Success, n (\%) & $41(87.2)$ & $36(76.6)$ & 0.18 \\
\hline Stone-free & $40(85.1)$ & $32(68.1)$ & - \\
\hline Residuel fragment $(<3 \mathrm{~mm})$ & $1(2.1)$ & $4(8.5)$ & - \\
\hline Residuel fragment $(\geq 3 \mathrm{~mm})$ & $6(12.8)$ & $11(23.4)$ & - \\
\hline Complication rate, n (\%) & $6(12.8)$ & 15 (31.92) & 0.026 \\
\hline \multicolumn{4}{|l|}{ Intraoperative complication } \\
\hline Mucosal injury, n (\%) & $2(4.3)$ & $1(2.1)$ & - \\
\hline Bleeding, n (\%) & $1(2.1)$ & $2(4.3)$ & - \\
\hline Perforation, n (\%) & $1(2.1)$ & 0 & - \\
\hline \multicolumn{4}{|l|}{ Postoperative complication } \\
\hline \multicolumn{4}{|l|}{ Minor complication } \\
\hline Fever (Clavien I), n (\%) & $1(2.1)$ & $3(6.4)$ & - \\
\hline Bleeding (Clavien I), n (\%) & $5(10.6)$ & $2(4.3)$ & - \\
\hline $\begin{array}{l}\text { Urinary tract infection } \\
\text { (Clavien II), n (\%) }\end{array}$ & $3(6.4)$ & 0 & - \\
\hline $\begin{array}{l}\text { DJ stent migration } \\
\text { (Clavien IIIb), } \mathrm{n}(\%)\end{array}$ & $2(4.3)$ & 0 & - \\
\hline
\end{tabular}

Min: Minutes, Sec: Seconds, DJ: Double-J, SD: Standard deviation, mm: Milimeter

study, 60\% stone-free rate was reported in 20 HSK patients. The average stone size was $17.8 \pm 4.5 \mathrm{~mm}$, the average operation time was $40.5 \pm 11.2$ minutes ( $\mathrm{min})$, the average scopy time was $29.4 \pm 14.8$ seconds (sc). Minor complication was seen in 5 patients but no major complication was seen (15). In our study, 15 procedures were made in 12 patients. The average stone size was $17.93 \mathrm{~mm}$; the average operation time was $49 \mathrm{~min}$, the average scopy time was $43.8 \mathrm{sc}$. and the stone-free rate was $83.33 \%$. Eryildirim et al. (24) reported that RIRS and PNL were safe and effective treatment methods for renal stones with HSK.

EK is seen in 1 in every 2200 to 3000 births. The anterior positioning of the renal pelvis, high insertion of the ureter and renal vascularization impair calyx drainage, increase stone formation risk. Injury risk of aberrant veins, neighboring abdominal organs and nerves make surgery difficult in EK patients (25). Demirkesen et al. (26) reported 38\% stone-free rate in EK patients after 3 session of SWL. Talic (27) reported $82 \%$ stone-free rate in 14 EK patients. In another study, 75\% stone-free rate for RIRS was reported in 4 SWL failed EK patients. Tortuous ureter makes renoscope difficult in EK (25).
In our study, there were 2 EK patients. None of these patients was stone free and intraoperative complications were observed.

$\mathrm{M}$ is a rare condition and occurs due to dystopia and abnormal blood circulation. EK and HSK anomalies usually accompany with anterior rotation (28). There are rare number of studies about kidney stone management in $\mathrm{M}$ patients. Mosavi-Bahar et al. (29) reported $81 \%$ success rate with no major complication in $5 \mathrm{M}$ patients. Binbay et al. (30) reported $77.3 \%$ success rate in $44 \mathrm{M}$ patients of 6 centers. In our study, 100\% success was achieved in one patient after 2 sessions with no minor and major complication seen.

RIRS and PNL are the most popular methods used in anomalous kidney stone treatment. In a study comparing RIRS and PNL for the treatment of anomalous kidney stones, Singh et al. (31) reported an algorithm-based approach. This approach was shaped according to factors like stone size, stone location, spatial calyceal orientation and the pelvicalyceal drainage system. In our study, we aimed to show our RIRS experience in kidney stones with different renal anomalies.

Demographic and stone characteristics such as age, gender, $\mathrm{BMI}$, previous surgery history, anticoagulant usage, preoperative DJ stent usage, stone number, laterality and localization were similar between the two groups.

When we examine intraoperative and postoperative data, average operation time, scopy time, hospitalization time, postoperative DJ stent rate and success rate were similar between the two groups.

The complication rate was statistically significantly lower in group N. Impaired urine drainage and changed anatomic structure could explain this finding (2). For group $A$, complications were seen in 15 of 47 procedures with 13 minor and major complications. Major complications were seen in CD and HSK patients, and we did not compare the subgroups.

The instruments used in RIRS are costly and was a major disadvantage and shortcoming. Also, they may deteriorate according to the surgeons experience and the number of procedures. In our study, only one flexible ureterorenoscope was used for the procedures.

RIRS may affect renovascular hemodynamics (32). In our study we found that RIRS has almost similar efficiency in anomalous kidney stones when compared with normal kidney stones. Meanwhile in anomalous kidney stones, more complications can be seen due to impaired anatomy and urine drainage (2). No serious complication was recorded in the normal and anomalous kidney stones groups. The small sample size could explain these findings. 


\section{Study Limitations}

Retrospective nature and low patient number were the limitations of our study. Prospective and larger sample sized studies are recommended.

\section{Conclusion}

RIRS can be used in the management of anomalous kidney stones. It is an efficient and safe method. Prospective and larger sample sized studies are needed to support this idea.

\section{Ethics}

Ethics Committee Approval: All procedures performed in studies involving human participants were in accordance with the ethical standards of the institutional and/or national research committee and with the 1964 Helsinki Declaration and its later amendments or comparable ethical standards.

Informed Consent: Informed consent was taken from all patients before the operation.

Peer-review: Internally peer-reviewed.

\section{Authorship Contributions}

Concept: S.S., M.Ç.Ç., I.G.K., A.L.S., A.N.K., Design: H.U.Ö., A.A., Ö.B., I.G.K., Data Collection or Processing: S.S., M.C.C., H.U.Ö., Analysis or Interpretation: M.Ç.Ç., A.A., Ö.B., I.G.K., A.L.S., Literature Search: S.S., H.U.Ö., M.Ç.Ç., Writing: S.S., M.Ç.Ç., H.U.O., A.N.K.

Conflict of Interest: No conflict of interest was declared by the authors.

Financial Disclosure: The authors declared that this study received no financial support.

\section{References}

1. Weizer AL, Silverstein AD, Auge BK, Delvecchio FC, Raj G, Albala DM, Leder $\mathrm{R}$, Preminger GM. Determining the Incidence of Horseshoe Kidney From Radiographic Data at a Single Institution. J Urol 2003;170:1722-1726.

2. Gross AJ, Fisher M. Management of stones in patients with anomalously sited kidneys. Curr Opin Urol 2006;16:100-105.

3. Raj GV, Auge BK, Assimos D, Preminger GM. Metabolic abnormalities associated with renal calculi in patients with horseshoe kidneys. J Endourol 2004;18:157-161.

4. Weizer AZ, Springhart WP, Ekeruo WO, Matlaga BR, Tan YH, Assimos DG, Preminger GM. Ureteroscopic Management of Renal Calculi in Anomalous Kidneys. Urology 2005;65:265-269.

5. Ray AA, Ghiculete D, RJ DAH, Pace KT. Shockwave lithotripsy in patients with horseshoe kidney: determinants of success. J Endourol 2011;25:487493.

6. Raj GV, Auge BK, Weizer AZ, Denstedt JD, Watterson JD, Beiko DT, Assimos DG, Preminger GM. J Urol 2003;170:4851.

7. Holman E, Toth C. Laparoscopically assisted percutaneous transperitoneal nephrolithotomy in pelvic dystopic kidneys: experience in 15 successful cases. J Laparoendosc Adv Surg Tech A 1998;8:431-435.
8. Puppo P, Bottino P, Germinale F, Caviglia C, Ricciotti G, Giuliani L. Flexible antegrade and retrograde nephroscopy: review of 50 cases. Eur Urol 1990;17:193-199.

9. Abe $R$, Etori $K$, Kato $T$, Sato K. Experience with transurethral ureteronephrolithotripsy using flexible nephro-ureteroscope. Nihon Hinyokika Gakkai Zasshi 1990;81:1667-1674.

10. Resorlu B, Unsal A, Gulec H, Oztuna D. A new scoring system for predicting stone-free rate after retrograde intrarenal surgery: the "resorlu-unsal stone score". Urology 2012;80:512-518.

11. Schoenthaler M, Wilhelm K, Katzenwadel A, Ardelt P, Wetterauer U, Traxer 0, Miernik A. Retrograde Intrarenal Surgery in Treatment of Nephrolithiasis: Is a 100\% Stone-Free Rate Achievable? J Endourol 2012;26:489-493.

12. Alcaide JRC, Elbers JR, Sánchez DL, González SP, Rodriguez, Bazán AA, Tous AR, Togores LH, Barthel JDLP. Flexible Ureterorenoscopy (URS): Technique and Results. Arch Esp Urol 2010;63:862-870.

13. Wendt-Nordahl G, Mut $T$, Krombach $P$, Michel MS, Knoll T. Do new generation flexible ureterorenoscopes offer a higher treatment success than their predecessors? Urol Res 2011;39:185-188.

14. 14.Baylan B, Sari S, Cakici MC, Selmi V, Ozdemir H, Ozok HU, Karakoyunlu AN, Topaloglu H, Sagnak AL, Ersoy H. Is RIRS Safe and Efficient In Patients With Kidney Stones Who Had Previous Open, Endoscopic Percutaneous Kidney Stone Surgery? One Center Retrospective Study. Urol J 2020;17:228231.

15. Oguz U, Resorlu B, Ozyuvali E, Bozkurt OF, Senocak C, Unsal A. Categorizing intraoperative complications of retrograde intrarenal surgery. Urol Int 2014;92:164-168.

16. Atis G, Resorlu B, Gurbuz C, Arikan 0, Ozyuvali E, Unsal A, Caskurlu T. Retrograde Intrarenal Surgery in Patients With Horseshoe Kidneys. Urolithiasis 2013;41:79-83.

17. Ergin G, Kirac M, Unsal A,Kopru B,Yordam M, Biri H. Surgical management of urinary stones with abnormal kidney anatomy. Kaohsiung J Med Sci 2017;33:207-211.

18. Van Cangh $P$, Smith $A D, N G C S$, Ost MC, Marcovich $R$, Wong $M$, Joyce $A D$, Desai RA, Assimos DG. Management of difficult kidney stones. J Endourol 2007;21:478-489.

19. Jones JA, Lingeman JE, Steidle CP. The roles of extracorporeal shock wave lithotripsy and percutaneous nephrostolithotomy in the management of pyelocaliceal diverticula. J Urol 1991;146:724-727.

20. Shalhav AL, Soble JJ, Nakada SY, Wolf JS Jr, McClennan BL, Clayman RV. Long-term outcome of caliceal diverticula following percutaneous endosurgical management. J Urol 1998;160:1635-1639.

21. Bellman GC, Silverstein Jl, Blickensderfer S, Smith AD. Technique and follow-up of percutaneous management of caliceal diverticula. Urology 1993;42:21-25.

22. Liatsikos EN, Kallidonis P, Stolzenburg JU, Ost M, Keeley F, Traxer O, Bernardo N, Perimenis P, Smith AD. J Endourol 2010;24:531-536.

23. Molimard B, Al-Qahtani S, Lakmichi A, Sejiny M, Gil-Diez de Medina S, Carpentier $X$, Traxer 0. Flexible Ureterorenoscopy With Holmium Laser in Horseshoe Kidneys. Urology 2010;76:1334-1337.

24. Eryildirim B, Kucuk EV, Atis G, Ozturk M, Senkul T, Tuncer M, Tahra A, Turan T,Koca O, Ates F, Yilmaz 0, Gurbuz C, Sarıca K. Safety and efficacy of PNL vs RIRS in the management of stones located in horseshoe kidneys: A critical comparative evaluation. Arch Ital Urol Androl 2018;90:149-154.

25. Cinman NM, Okeke Z, Smith AD. Pelvic Kidney: Associated Diseases and Treatment. J Endourol 2007;21:836-842.

26. Demirkesen O, Yaycioglu O, Onal B, Kalkan M, Tansu N, Yalcin V, Kural $A R$, Solok V. Extracorporeal shockwave lithotripsy for stones in abnormal urinary tracts: analysis of results and comparison with normal urinary tracts. J Endourol 2001;15:681-685. 
27. Talic RF. Extracorporeal shock-wave lithotripsy monotherapy in pelvic ectopia. Urology 1996;48:857-861.

28. Oğuz U, Balci M, Atis G, Bozkurt OF, Tuncel A, Hali F, Aslan Y, Yildirim IO, Senocak C, Yordam M, Atan A, Caskurlu T, Unsal A. Retrograde Intrarenal Surgery in Patients With Isolated Anomaly of Kidney Rotation Urolithiasis 2014:42:141-147.

29. Mosavi-Bahar SH, Amirzargar MA, Rahnavardi M, Moghaddam SM, Babbolhavaeji H, Amirhasani S. Percutaneous nephrolithotomy in patients with kidney malformations. J Endourol 2007;21:520-524.

30. Binbay M, Istanbulluoglu O, Sofikerim M, Beytur A, Skolarikos A, Akman T, Huri E, Ozturk B, Kural AR, Muslumanoglu AY. Effect of Simple Malrotation on Percutaneous Nephrolithotomy: A Matched Pair Multicenter Analysis. J Urol 2011;185:1737-1741.

31. Singh AG, Jairath A, Balaji SS, Tak G, Ganpule AP, Vijayakumar M, Sabnis $R B$, Desai MR. Changing trends in the endourological management of urolithiasis in anomalous kidneys. BJU Int 2019;123:318-327.

32. Öztekin Ü, Erkoç F, Sarı S, Selmi V. Effect of Simple Malrotation on Percutaneous Nephrolithotomy: A Matched Pair Multicenter Analysis, Abdullah Gürel, Fatih Ataç. The Effect of Ureterorenoscopy and Retrograde Intrarenal Surgery Procedures on Renovascular Hemodynamics. Published online: 25.11.2019. DOI: 10.4328/ACAM 20066 